\title{
THE ROLE OF MASS MEDIA AND MINANGKABAU IDENTITY
}

\author{
Wannofri Samry \\ Andalas University, Padang, Indonesia
}

\begin{abstract}
Since early of twentieth century mass media is one of the professional jobs which they done By Minangkabau People, both as journalist or auhtor and publisher. Beside as teacher carier, It seems that the mass media is the professional field that done ealiest of them. Establishing of Minangkabau identity is closely ralated to existence of mass media; with mass media progressing and having dialectic. The intelectual richness of Minangkabau since the early 20th century was known at national level is also not separated from the existence of mass media. Their identity also determained by the mass media; locality, nationalism and globalization influences are processed in mass media to form different Minangkabau world from time to time. This paper presents the establishing of the identiy of Minangkabau people through the mass media on various problem in a historical perspective, mainly after 1950's.
\end{abstract}

Key words: mass media, journalist, Minangkabau, identity, historical 


\section{INTRODUCTION}

The Minangkabau people are ethnic who inhabit Central Sumatra or West Sumatra Province. According to Loeb (1974: 96) the Minangkabau name was only used since $1365 \mathrm{M}$. This ethnicity had an educational tradition rooted since the heyday of Islamic influence at 18th century (Azyumardi Azra in Oman Fathurrahman, 2008: 9-10) and influence of the western education at 20th century (E. Grave, 2007; Mansoer et. Al., 177-185). The influence of this education has prompted West Sumatra people to enter the modernization somewhat earlier and have a significant influence on the development of Indonesian nationality. Modernization of education has also encouraged West Sumatra people to more quickly enter the professional world such as journalists, teachers, bureaucracies, entrepreneurs and so on (Taufik Abdullah, 2018; Usman Pelly 1998: 158172. Publishing Mass media is one of the earliest professional work entered into West Sumatra, since the beginning of the 20th century a number of mainstream mass media publications were dominated by Minangkabau people, although the change in roles always occurred in accordance with changing times, at least until the early 2000s the middle part Minangkabau people were still dominant This can be seen from the circulation of mass media and the existence of journalists in this region.

\section{Mass Media and Identity}

Mass media is a important role in modern world. Some researchers remark that mass media have influenced in some aspect in our life, social and political action, culture and

identity (Osmo A Wiio in Martin and Chaudhary, 1997: 120-131). Ben Anderson (2001) adressed that mass media play special role in establishing nationalism identity: Some have played role to rise up the nastionalism and make display inter ethnics and nations. Amartya Sen (2007) said that mass media have an enormous influence in helping to shape public opinion and underlying sentiment. The media is also an important accountability mechanism: it raises important issues, corruption for example, that might otherwise never be publicly debated or addressed. The media also has an important role in stimulating governments to take action on social policy.

The issue of preserving cultural identity in the complex process of globalization is twofold. On the one hand there is the danger of cultural homogenization, which means that people could reach to one single form of culture, and on the other an acute cultural and psychological disintegration for 


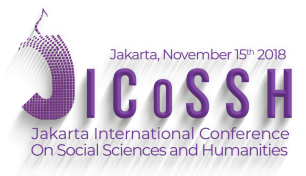

both individuals and society. Both risks are correlated. There is a form of behavior, often unconscious, which appears to some as a form of cultural aggression. Another name for it would be ethnocentrism wrong led (Sebastian Andrei Labeș, 2015)

Daniel Perret (2010: 15) in his study at northeastern Sumatra say that identity is the interdependent relationship that takes place between spaces and along the network that connects two or several groups of people. So that identity can transformed, it is depended situation and time. Promotion of identity in this research show some fact which East Sumatra identity can change from outside influences.

A series of writings can be red such as Wannofri Samry, "Penerbitan Akhbar dan Majalah di Sumatera Utara 1902-1942: Proses Perjuangan identitas dan Nasionalsime (2013), "Medan Press: National Identity Finding Process ", Historia Vol. XII, no. 1 (Jun 2011), "Ideas and Activities of Journalists of Minangkabau Women in the Dutch Colonial Period", Jebat: Malaysian Journal of History, Politics and Strategic Studies, 2012, 39 (2). In these studies it is shown that mass media have a important's role in the formation of ethnic and national identity.

\section{PROBLEM AND METHOD}

The focus of this study is framing the mass media on local identity. This study examines the content of printed mass media published in West Sumatra which has been published since the 1960s until 2017. In addition, the study was also supplemented by focused group discussions. We have invited editors and journalists and writers and expressed their experiences and views

freely. This research has used hundreds of mass media documents from the 1960s to the 2000s. Mass media documents were obtained in the regional library of West Sumatra Province, Singgalang Daily, Haluan and private collections of journalists in West Sumatraa. Besides that, an interview with the founder of Singgalang Daily was also conducted, a newspaper that was quite representative of the Minangkabau. Descriptions and experience in managing newspapers at the local level were also explored from the experiences of journalists and autobiographers

\section{RESULT}

For West Sumatra in the 1960s was a very important year for the history of mass

media. At that time were the years of recovery from the chaos and traumatics caused by the PRRI which erupted in 1958. In Chairul Saleh's term, a Minangkabau figure in Jakarta, that "urang 


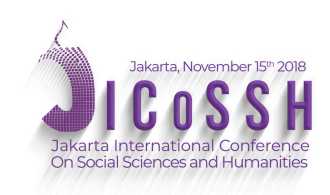

kampuang awak Alah Muno" (Navis 1986), Minangkabau people have lost their identity after their defeat in the PRRI war.

As the Minangkabau people always said after PRRI and during the New Order period, the Minangkabau ethnic group entered into a period of restoration of self-esteem, the time of mambangkik batang tarandam (lift the submerged stem). Harun Zain claimed politically that after the PRRI of the Minangkabau people felt devastated, they were ashamed to claim to be Mianangkabau people (Abrar Yusra, 1997: 111)

Physically PRRI has destroyed the Minangkabau country. Thousands of people were killed and thousands were injured and missing. After that there was a massive exodus of Minangkabau people outside their area to avoid war and cover up shame as people lost. The defeat also encouraged the development and hegemony of the Indonesian Communist Party (PKI) in West Sumatra (Hasril and Khairul, 1998 p. 306-307 and 319).

The political defeat was recognized by a number of Minangkabau experts and people. The truth of the statement was shown by many Minangkabau people hiding their identities; Their children who were born after PRRI were given the name "O", as Javanese ethnic names. Although this can still be questioned and traced the truth, the 1960s at least became a time when Minangkabau people reorganized their identities, both in ethnic contexts and in national contexts. There is a phenomenon that they are trying to protect themselves by join together into the New Order's political power, so that the development of their country which is destroyed by war can be rebuilt. Second, they want to play their original role back in the intellectual world as before independence. They realized that the biggest contribution of the Minangkabau people to the Indonesian people was ideas and intellectual property. So on,

things that were difficult to avoided, they became the main supporters of the New Order regime. Golkar's victory in West Sumatra during the New Order was a historical fact that could not be ignored. The power of the New Order certainly greatly influenced the development of the next Minangkabau people. Changes in the political and nagari system also influence cultural development.

The most important thing is the role of the mass media in "mambangkik batang tarandam" or rebuilding after being destroyed after the PRRI. The term "Batang Tarandam" is taken from the habits of Minangkabau people who often soak wood to make a house in a pond before use, in order to prevent it from caterpillarsAfter PRRI some Minangkabau intellectuals, journalists and activists, 
who used to write in the mass media often gathered and discussed; they tried to contribute their thoughts and energy in rebuilding West Sumatra. They are often involved in mass media publishing. Indeed, in the early 1960s in West Sumatra only two newspapers were published, namely Res Publika, then changed their name to Persatuan. Respublika is a mouthpiece for the Indonesian National Party and Persatuan is the newspaper of the Indonesian Communist Party (PKI) (Pasni Sata, 1994: 270). In 1963 the Aman Makmur newspaper was published. Aman Makmur claims to be an independent mass media (Pasni Sata: 1994; 271). The Aman Makmur's motto is "For Regional Development for Nation Welfare. In addition to presenting general information such as social and economic Aman Makmur also provides space for Minangkabau cultural problems. The rubric that specifically presents indigenous issues and development in West Sumatra is contained in the Adat and Limbago rubrics (Hanum: 1993).

The printing of Aman Makmur was the result of a discussion between several Minangkabau figures who were concerned about West Sumatra after the PRRI. The leaders who encouraged the establishment of this newspaper were mainly Muhammad Yamin, a movement figure and thinker whose reputation was recognized at the national level. Yamin's idea was supported by Chairul Saleh and Hasjim Ning. these three figures are members of Murba Party which led by Tan Malaka. Yamin and Chairul Saleh were close to Soekarno. These figures advised young journalists in Jakarta to immediately return home to establish an anti-communist newspaper, in order to revive the Minangkabau after their destruction after the defeat of the PRRI. Thanks to financial assistance from Hasjim Ning's businessman Aman Makmur published in 1963 (Kahin, 2005: 371; A.A. Navis, 1986, p. 197).

The publication of mass media in the 1960s was influenced by political condition. Politics at that time were divided into several streams. National, religious and communist. However Sukarno tried to combine these ideology with Nasakom (Nationalism, Relegius and

Comunist) by referring to the Political Manifesto (Manipol) in 1959; The 1945 Constitution, Indonesian Socialism, Guided Democracy and Guided Economy (USDEK). Soekarno stressed that the revolution had not been completed and had to be continued (Soekarno: 1959). While Hatta reminded Soekarno that the revolution should not be too long because it could destabilize the unity of nation (Hatta: 1960; Feith \& Castle, 1988). The slogan that developed in the 1960s namely "politics was the commander". Political conditions like this gave the PKI more room after 1955. Some cases showed the closeness of Soekarno with the Indonesian Communist Party. Broadly speaking there are three forces of political polarization that developed in the 1960s, namely 
Soekano-PKI (Indonesia National Party-Indonesia Comunist party and its supporters), IslamSocialists (Masjumi Party-Socialist Party and supporters) and the anti-communist Army. This kind of polarization also colored politics at the local level, and also influenced journalists and mass media.

In December 1968 was born the Minangkabau language Singgalang weekly newspaper which was initiated by several young West Sumatra intellectuals who were concerned about the Minangkabau after the Minangkabau destruction on two occasions; namely the PRRI civil war in 1958 and the September 30, 1965 movement. The Singgalang Daily was initiated and sought by a number of Minagkabau intellectuals who were very concerned about the Minangkabau condition after PRRI. The initiators were Nazif Basir, Nasrul Siddik, Salius Sutan Sati and then joined Basril Jabbar, a young Minangkabau businessman who had intellectual attention. Singgalang in those years is published once a week using Minangkabau language. In the first year the Singgalang newspaper achieved 27,000 copies (Abrar Yusra et. Al., 2016: 9). To improve the quality of this newspaper since the 1980s it has recruited young intellectuals, especially those from the Minanggkabau ethnic group; talented authors and journalists in West Sumatra and around Riau. Several journalists who had worked at Singgalang daily later became famous writers and journalists in Indonesia. It is very appropriate if Singgalang daily is often said to be a school for journalists and authors. Singgalang Daily is often regarded as a college that gives birth to leading journalists and authors at every time.

The New Order period was also considered in the terminology "mambangkik batang tarandam". During this period Haluan reapeared. The real direction has begun to emerge during the Second Dutch Aggression, precisely 1 May 1948 at Bukittingi. The founders of this newspaper are Adaham Hasibuan, Kasoema and Amarullah Ombak Lubis. Because of paper shortages or conditions of war, this newspaper stopped publishing. On September 1, 1949 the Haluan newspaper was published again in Padang led by Kasoema (Kasoema, 1958;

Nazif Basir,; 1995: 292; Basrizal Koto, 2011). In 1958 the Haluan was prohibited from being published by the government because it was considered against the Central Government and voiced PRRI. The Haluan was issued again in 1969 after being given a recommendation by Military Regional Command (Kodam 17 Agustus). Since the PRRI rebellion, the Haluan daily was suspected as a rebbelion newspaper and their journalists were suspected by the central government (Chairul Harun in Abrar Yusra, 1994: 282). It was different when in New Order Rezim began his power. The content and style of the Haluan in the New Order period is certainly different from the 1950s; after republishing the newspaper it is more likely to become a "development newspaper", 


\section{Jicossh}

it becomes a medium of communication between the government and the people. Since that time the Haluan news felt neutral. After the death of Kasoema, the owner of the Haluan Daily, the newspaper went bankrupt. In 2010 Haluan was purchased by Basko Group. Now this newspaper has developed into 3 branches, namely Haluan Padang, Haluan Riau in Pekan Baru and Haluan Riau Kepri on Batam.

During the New Order there were 3 mainstream newspapers in West Sumatra, Singgalang Daily, Haluan and Spirit. In 1986 a weekly Minangkabau language, Canang, appeared, but it did not become a mainstream newspaper. This newspaper only survived until 2003. The newspaper stopped publishing because it went bankrupt. Haluan and Singgalang persist to this day, these two newspapers seem to have become a part of the icon of West Sumatra and of course Minangkabau.

The issuance of the Singgalang newspaper was initially felt to be satisfying by its founders, Nazif Basir and Nasrul Siddik, because the newspaper had presented the Minangkabau genre journalism and the circulation aspect was quite high, 27,000 (Abrar Yusra et. Al., 2016: 9-10). In side of a business aspect, the post-1980 direction became a strong publishing company in Minangkabau. The success of Singgalang is often suspected by its founders and administrators because the Minangkabau journalistic genre is mixed with Indonesian so the reading feels funny. One of the sections of the favorite Singgalang weekly in the early years included "Awak Samo Awak = we are with us " ( written by Nasrul Siddik under the pseudonym Inyiak Lunak). The content of this space is about the daily lives of grassroots Minangkabau people; or the Mianangkabau grass root identity (Abrar Yusra, et. Al, 2016: 13).

KEEPING LOCAL IDENTITY In general, newspapers of West Sumatra always provide space for modernization, the outside world and in some newspapers space is also created to protect and revitalize the Minangkabau identity. After independence ( the 1950s) newspapers published in West Sumatra contained a lot of news and articles about development. Some of the sections speak Minangkabau and some speak Indonesian. Before independence, many newspapers that speak Malay, Minangkabau and sometimes use Dutch. But there is no newspaper that is fully Minangkabau language except Canang Weekly in 1986. But newspapers like this don't last too long. In general, the newspapers published in West Sumatra after the 1960s used Indonesian, in certain parts the content was in the Minangkabau language.

Since the time of the movement of newspapers in Minangkabau often contained works of art and culture and space for Minangkabau customs. Newspapers published in the 1960s also have such content, only in the 1960s did the political nuance be higher, the conditions of national political 


\section{Jicossh}

development were also expressed at the local level. For example, when the cultural manifest was announced in 1964 (Majalah Sastra no 9/10 Th III 1963) by two prominent writers and culturalists, Wiratmo Soekito and H. B. Jassin, West Sumatra writers were divided into two groups. The first is the Manifesto support group which rejects "politics as commander"; the second is a group that rejects the Cultural Manifesto because it is considered not to obey Soekarno's political line. The second group generally were followers of the pro-Sukarno Indonesian National Party (PNI) and the Indonesian Communist Party (PKI). Supporting groups of the Cultural Manifesto were journalists working at Res Publika and later publishing Aman Makmur, while pro-Sukarno and Communists were journalists working on the daily Information / Sound of Unity (Abrar Yusra, 2016: 7).

If you read the contents of the mass media which was published in West Sumatra, you will see cultural riches in them. Various local content is loaded. Customary space and culture are always there. Even traditional and cultural debates are published. This is important in maintaining and establishing identity. Because content like that the reader becomes interested. Customary and cultural content is also a part of a strategy to restore self-esteem or pride that has been destroyed since the late $1950 \mathrm{~s}$.

In the 1960s, after losing the PRRI war, the Aman Makmur newspaper was used as a strategy section to restore self-esteem, "mambangkik batang tarandam" for the Minangkabau ethnic group. One rubric in the newspaper that is very important is Adat and Limbago. Once a week in this space the writer talks about the intricacies of adat for the Minangkabau people and the repositioning of the princes and ninik mamak in Minangkabau culture. The appeal that is always raised is the need for custom and culture to adapt to the times for nagari development (Hanum, 1993: 24). One quote from the Aman Makmur newspaper is as follows:

"The role of ninik mamak (uncle, leader in matrilineal system) is in marriage, death and cultural events that are not closely related to social and economic problems. The changing of this role is because the child and niece has known Western education along with its cultural values, the community knows liberalism and the public knows the age of the national revolution with the values of Pancasila socialism. In addition, he was also troubled by the economic life of his child and wife or he was left behind by his nephew who had known education in overseas. This causes the niece not to understand much about family law as a traditional advice. While on the other hand because its function as a ninik mamak still wants to do a advice, "kamanakan baraja ka mamak, mamak baraja ka panghulu, penghulu baraja ka alua and patuik= nephew learns to uncle, uncle 
learns to the leader of clan, the leader learns in accordance with the system and truth". There are difficulties in how to restore the old value, while the present value is different, so the solution is that people adjust to the situation and make a new assessment of customs advice in accordance with the current situation and keep up with the development of scientific and medical organizations "( Aman Makmur tt November 1964 in Hanum, 1993: 22)

Such facts have long been a discourse for Minangkabau intellectuals and journalists. Since the development of Western education and modernization entered various cultural aspects of Minangkabau, the response and discussion about customs and culture always became an interesting topic. In the 20th century mass media became the right space to channel anxiety about cultural change. Taufik Abdullah (1972) said that Western modernization had made polarization in Minangkabau culture and then caused conflict. But with the mass media, conflict can be physically suppressed but the tension moves into the form of writings and later also in the form of paintings and caricatures.

After the G30S PKI event in 1965, the restoration of self-esteem and changes in Minagkabau's identity remained an interesting theme for the mass media. This is indicated by the motto and rubric of mass media content. Even now, Singgalang Daily Motto "Building Self-Esteem for Nusa Welfare and Nation." At first Singgalang used the motto "Prioritizing Entertainment, Culture and Knowledge." This initial motto was used, of course, a lot of considerations, it could be that Singgalang Daily considered two political events that were very hot short period. The PRRI rebellion and continued with the regional central political battle and the September 30 PKI Movement in 1965. But the existence of the Singgalang publishing was a strong effort to Minangkabau-kan. This right can be seen from the news titles that speak a lot of Minangkabau, even though the contents are in Indonesian. Some contents are also written in Minangkabau. Some of the names of the rubric in the

Minangkabau language include Jariah Manantang Buliah, Raun Sabalik, Kaba Bagalau, Pantun Balega, Tanbaro caricature rubric, Iduik Baraka Mati Bariman, Kalene Capeklah Gadang and serialization of Alang Bangkeh. The article titles in the 1960s until the 1970s were dominated by the Minangkabau language, although the contents were written in Indonesian. This became Singgalang's identity and the pride of his owners and journalists (Abrar Yusra, 2009: 89-90).

The Haluan has the motto "Educating Community Life". After PRRI it was better known as a newspaper that voiced the development of West Sumatra. The experience of banning during the PRRI period in 1958 made the decision more vigilant so as not to be considered to embrace 


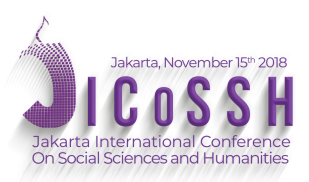

provincialism. The presence of Haluan tried as a press that devoted its publishing to the interests of west Sumatera people. The content is to educate the life of the nation, defend the weak people, uphold the law and justice, and try to inspire. His contribution to Minangkabau is in the context of development. The Haluan remains on an independent track, not tied to groups and parties in carrying out social control. Haluan wants to continue to maintain the civilized values that develop in the community, especially the values of Aday basandi syarak, syarak basandi Kitabullah=customes based on Islamic law, the law based on Al Quran (ABS SBK) as those embraced in the Minangkabau culture. 


\section{REFERENCES}

A.A. Navis, 1986. Pasang Surut Pengusaha Pejuang: Otobiografi Hasjim Ning, Jakarta: Grafiti Pers.

Abrar Yusra, 1994. Otobiografi A.A. Navis Satiris dan Suara Kritis dari daerah, Jakarta: Gramedia Pustaka Utama.

Abrar Yusra, ed., 1997. Tokoh yang Berhati Rakyat: Biografi Harun Zain, Jakarta: Gebu Minang.

Abrar Yusra et. al, 2016. Bung Nasrul Siddik, Jakarta: Teras Cajrawala Ilmu. Abrar Yusra, 2009. H. Basril Djabar Sahabat Kita, Padang: Genta Singgalang Press. Abrar Yusra, ed. 2009. Sekali di Daerah tetap di Daerah: Otobiografi H. Basril DJabar

Sebagaimana Dituturkan kepada Abrar Yusra, Padang: Genta Singgalang Press. Azyumardi Azra, 2003. Surau Pendidikan Islam Tradisional dalam Transisi dan

Modernisasi, Yogyakarta: Logos. Anderson, B, 2001. Imagined Commuunity: KomunitasKomunitas Terbayang, Yogyakarta:

Insist. Feith, Herbert, \& Lance Castles, ed., 1988.. Pemikiran Politik Indonesia 1945-1965, Jakarta: LP3ES Grave, E.E. 2007. Asal-Usul Elite Minangkabau Moderen Respons TerhadapKolonial

Belanda Abad XIX/XX, Jakarta: YOI. Halida Hanum, 1993. Surat Kabar Aman Makmur 19631971, thesis Degree, Faculty of Letters, Andalas University.

Hasril Chaniago \& Khairul Jasmi, 1998. Brigadir Jenderal Polisi Kaharoedin Datuk Rangkayo Basa, Jakarta: Sinar Harapan.

Harian Haluan, 1970-2017. Harian Singgalang 1969-2017. Jansson, David R, 2003. “American National Identity and The Progress of the New South in

National”, Geographical Review; 93 (3) p. 350 Kasoema, 1958. Persuratkabaran di Sumatera Tengah in Kenangan Sekilas Sejarah

Perdjuangan Pers Sebangsa, Jakarta: SPS. Labeș, Sebastian Andrei, n.y. "Globalization and 


\section{Cultural Identity Dilemas", CES Working}

Papers - Volume VI, Issue 1 Loeb, Edwin M., 1972. Sumatra Its History and People, Kualalumpur-Jakarta: Oxford

University Press. Maryn, L John and Anju Chaudary, 1997. Sistem Media Massa Suatu Perbandingan,

Kualalumpur: Dewan Bahasa dan Pustaka. M.D. Mansoer, et.al. 1970. Sedjarah Minangkabau, Jakarta: Bhratara. Mohammad Hatta, 1960. Demokrasi Kita, Jakarta: Pustaka Antara P.T. Oman Fahurrahman, 2008. Tarekat Syatariyah di Minangkabau, Jakarta: Prenada Media

Group-EFEO-KITLV. Perret, Daniel, 2010. Kolonialisme dan Etnisitas: Batak dan Melayu di Sumatera Timur,

Jakarta: KPG-EFEO-P3AN. Usman Pelly, 1998. Urbanisasi dan Adaptasi Peranan Misi Budaya Minangkabau dan

Mandailing, Jakarta: LP3ES. Saafroedin Bahar, 2015. Etnik, Elite dan Integrasi Nasional : Minangkabau 1945-1984, Republik Indonesia 1985-2015, Yogyakarta: Gre Publishing. Sen, Amartya, Ed. 2007. Peace and Democratic Society, Open Book Publishers. Katić, Mario, Nataša Gregorič Bon, John Eade, 2017. ’Landscape and heritage

Interplay:Spatial and temporal explorations" pp. 5-18 in Anthropological Notebooks, XXIII/3,

Taufik Abdullah, "Modernization in the Minangkabau world: West Sumatera in Early Decades of theTwentieth Century" in Claire Holt, Culture and Politic in Indonesia, Singapore: Equinox Publishing PTE LTD, 2007.

Taufik Abdullah, 2018. Sekolah dan Politik: Pergerakan Kaum Muda di Sumatera Barat 19271933, Yogyakarta: Suara Muhammadyah.

Wannofri Samry,2013. "Penerbitan Akhbar dan Majalah di Sumatera Utara 1902-1942: Proses perjuangan Identiti dan Nasionalisme. Disertasi PhD, Universiti Kebangsaan Malaysia.

Wannofri Samry, 2011. "Medan Press: National Identity Finding Process ", Historia Vol. XII, no. 1 


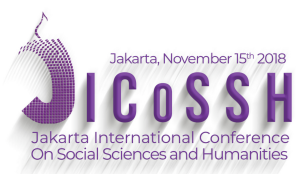

Wannofri Samry, 2012. "Ideas and Activities of Journalists of Minangkabau Women in the Dutch Colonial Period", Jebat: Malaysian Journal of History, Politics and Strategic Studies, 39 (2). 